\title{
Intraoperative hyperglycemic stress response and tissue perfusion in cardiac surgery
}

\author{
Aslı Demir ${ }^{1}$, EDA BALCI ${ }^{1}$, Hülya Yiğit Özay ${ }^{1}$, and MELIKE BAHÇECITAPAR ${ }^{2}$ \\ ${ }^{1}$ Ankara City Hospital Anesthesiology Department \\ ${ }^{2}$ Hacettepe Universitesi
}

October 17, 2021

\begin{abstract}
Background and aim of the study Approximately 30\% of patients undergoing cardiac surgery have a history of diabetes and $60-80 \%$ of patients without diabetes have stress hyperglycemia. We examined patients undergoing cardiac surgery to determine the presence of stress hyperglycemia and its relationship to tissue perfusion. Methods Hemodynamic parameters, central venous oxygen saturation, lactate, oxygen delivery and consumption, oxygen extraction rate were analyzed at four intraoperative time points. Results The stress-induced hyperglycemic response during cardiac surgery was more severe in patients without diabetes. When focusing on the oxygen extraction rate in terms of tissue oxygenation, diabetic patients had 1.22 times higher and significant oxygen extraction rate than non-diabetic patients. Conclusions Although lactate values were slightly higher and central venous oxygen saturation were slightly lower in the diabetic group, considering the fact that oxygen extraction rate reflects the total outcome of small changes in all these parameters, we can emphasize the conclusion that diabetic patients undergoing cardiac surgery have greater tissue oxygen demand/supply imbalance compared to non-diabetic patients. In our study, this tissue oxygenation defect in diabetic patients was not found to be directly correlated with blood glucose levels. Perhaps, even if the disease is under control, the negative effects of diabetes on all systems have accumulated and led to such a result.
\end{abstract}

\section{Introduction}

The term stress hyperglycemia describes transient increases in blood sugar in patients without a history of diabetes mellitus (DM) that occur during acute illness or stress. Hyperglycemia seen in cardiac surgery patients is important in terms of its severity and its relationship with postoperative complications. ${ }^{1-3}$ Intraoperative hyperglycemia has been associated with increased morbidity in diabetic patients. ${ }^{4}$ Mortality has also increased in diabetic and non-diabetic hyperglycemic patients who underwent cardiac surgery with cardiopulmonary bypass (CPB). ${ }^{5}$ Approximately $30 \%$ of patients undergoing cardiac surgery have a history of DM and approximately $60-80 \%$ of patients without DM have stress hyperglycemia, which is defined as blood glucose value above $140 \mathrm{mg} / \mathrm{dL} .^{6-8}$ It is thought that certain disorders in glucose metabolism such as increased levels of insulin resistance, cortisol, adrenocorticotropic hormone (ACTH), growth hormone (GH), epinephrine and norepinephrine during cardiac surgery and CPB in patients with and without DM contribute to hyperglycemia. ${ }^{9}$

The key determinants to maintain of tissue perfusion and cellular integrity are adequacy of macrocirculation and delivery of oxygen at values exceeding the current rate of consumption. ${ }^{10}$ Oxygen extraction rate $\left(\mathrm{O}_{2}\right.$ ER $)$ is the ratio of the body's oxygen consumption $\left(\mathrm{VO}_{2}\right)$ to systemic oxygen delivery $\left(\mathrm{VO}_{2} / \mathrm{DO}_{2}\right)$, which is a practical way to describe the adequacy of systemic oxygen delivery. ${ }^{11}$

To our knowledge, there are no previous studies focusing on tissue perfusion-related outcomes with the degree of hyperglycemia that may occur in cardiac surgery patients with and without a history of DM. 
We hypothesized that stress hyperglycemia may be correlated (or associated) with reduced tissue perfusion during cardiac surgery, therefore, we closely examined a series of consecutive cases undergoing cardiac surgery to determine the presence of stress hyperglycemia and its relationship to tissue perfusion. Primary outcome measures were associated with stress hyperglycemia and tissue perfusion parameters in non-diabetic patients undergoing cardiac surgery and patients with non-insulin-dependent diabetes mellitus (NIDDM). Data may be relevant for tailored intervention and proper management.

\section{Material and Methods}

This was a observational longitudinal study and was conducted in accordance with the principles of the Declaration of Helsinki. The study was approved by the Ethics Committee for Clinical Research at local hospital (11.01.2019, 29620911-929-67). Ninety consecutive adult patients of the American Society of Anesthesiologists (ASA) Class II-III who underwent elective cardiac surgery with CPB over a 2-months period were included in this study. Patients undergoing emergency or re-do surgery, off-pump surgeries, transplant surgeries, vascular surgery were excluded from the study. Patients with insulin dependent diabetes mellitus (IDDM), those with a history of ejection fraction under $40 \%$ or pulmonary, renal or hepatic failure, those with hematologic disorder, those under 18 years old or those using alcohol, or any medication suppressing stress response as corticosteroids, vitamin C, or n-acetylcysteine, were not included the study. Since IDDM has a different pathogenesis, it was excluded from the study, considering that it may interact more negatively with tissue perfusion parameters. NIDDM patients discontinued their oral antidiabetic medications 24-hour before surgery. So the aim of this study is to evaluate the degree of stress response and related tissue oxygenation parameters in NIDDM patients whose documented preoperative normoglycemia with oral antidiabetic drug use and patients without DM.

Pulse oximetry, five channel electrocardiography, invasive blood pressure monitoring, bispectral index monitoring (BIS, Covidien, MN, ABD) and invasive internally calibrated pulse wave analysis (ProAQT; Pulsion Medical Systems, Feldkirchen, Germany; $\left.\mathrm{PPV}_{\mathrm{ProAQT}}, \mathrm{CO}_{\mathrm{ProAQT}}\right)$ were performed. As baseline measurement, patients received an initial hemodynamic assessment based on stroke volume, cardiac output (CO), and mean arterial pressure. $\mathrm{DO}_{2}\left(\mathrm{CO} \times\right.$ arterial content of $\left.\mathrm{O}_{2}\right), \mathrm{VO}_{2}(\mathrm{CO} \times$ [arterial-venous content of $\left.\mathrm{O}_{2}\right]$ ), and $\mathrm{O}_{2}$ ER calculations were performed with these calculated $\mathrm{CO}$ values by pulse wave analysis. However, when the $\mathrm{CPB}$ was initiated, pump flow was used as $\mathrm{CO}$ value due to inaccurate pulse wave analysis measurements during CPB.

Patients with no history of DM prior to surgery, may exhibit transient elevation of blood glucose $>180 \mathrm{mg} / \mathrm{dL}$ during cardaiac surgery and cardiopulmonary bypass, they may have insulin resistance. We treated with a single or intermittent dose of intravenous insulin to maintain glucose [?] $180 \mathrm{mg} / \mathrm{dL}$ at these patients. After a single dose insulin push therapy, blood glucose levels were re-evaluated and intravenous insulin regimen was started when necessary as recommended by Duggan et al. ${ }^{12}$ An endocrinology consultation was obtained in the postoperative period in case DM was detected in some of these patients. In patients with NIDDM, the bolus dose calculated with the formula (blood glucose value - 100/40) was applied when blood glucose was above $180 \mathrm{mg} / \mathrm{dl}$. Then blood glucose value/100 units/hour infusion dose was started. ${ }^{12}$ Blood glucose levels were monitored with half an hour intervals.

Following adequate activated clotting time $(>480 \mathrm{sec})$, cannulation were performed and CPB was initiated. $\mathrm{CPB}$ was performed in moderate hypothermia $\left(28-31^{\circ} \mathrm{C}\right)$. Hemoglobin concentrations were kept above 7.5 $\mathrm{g} / \mathrm{dl}$ during operation.

Blood samples were collected from the radial artery and internal jugular vein. Although jugular venous $\left(\mathrm{ScvO}_{2}\right)$ and mixed venous oxygen saturation values differ slightly, it is acceptable to use $\mathrm{ScvO}_{2}$ instead of mixed venous oxygen saturation. ${ }^{13}$ Blood glucose and gas analysis were performed at four time points: after the induction of anesthesia before the surgery as baseline values (T1), at the $5-10^{\text {th }}$ minute of CPB (T2), at the $30-40^{\text {th }}$ minute of CPB (T3), and while the sternum was closing (T4). At these four time points, hemodynamic parameters, central venous oxygen saturation $\left(\mathrm{ScvO}_{2}\right)$, lactate level, oxygen delivery $\left(\mathrm{DO}_{2}\right)$, oxygen consumption $\left(\mathrm{VO}_{2}\right)$, oxygen extraction rate $\left(\mathrm{O}_{2} \mathrm{ER}\right)$, mean arterial pressure (MAP) and urine output 
values were recorded.

\section{Statistical analysis}

All statistical analyses were performed using IBM SPSS 22.0 for Windows. Kolmogrov-Smirnov and Shapiro Wilk tests were used for evaluating whether the observations are from the normal distribution. In describing the features of data, number of cases (n) and their proportions (\%) for categorical variables, median and range for non-normally distributed continous variables and mean and standard deviation for normally distributed continous variables were calculated. Pearson chi-square or Fisher Exact test was used to compare NoDM and NIDDM groups according to categorical variables. The Mann-Whitney U test or two sample t-test were used to compare NoDM and NIDDM groups for continous data obtained from basic features of patients such as age, weight and height. According to the other continous variables, these two tests were also used for the comparison of NoDM and NIDDM groups at each time point. Additionally, the longitudinal data sets in this study were analyzed by a linear regression model with Generalized Estimating Equations (GEE) method which can be applied for normally or non-normally distributed measurements of same patients over time. In GEE analyses, working correlation matrix was assumed to be unstructured. The results of GEE method are corresponding to overall comparison of two groups over all four time points. A p-value $<0.05$ for two-sided tests was considered statistically significant.

\section{Results}

A total of 90 patients who underwent cardiac surgery at the Cardiothoracic Surgery operating room in tertiary city hospital were included in the study. Seven patients were not analyzed due to lost of follow-up. NIDDM was detected in 19 of 83 patients included and determined as group NIDDM, the remaining nondiabetic 64 patients were determined as group NoDM. In only 5 patients in the non-diabetic patient group, blood glucose levels did not exceed 140 during the operation, so the rate of stress hyperglycemia was $78 \%$. In the NIDDM group, blood glucose levels were high from the beginning.

Pre-operative and intra-operative demographic and clinical characteristics of the study population are summarized in Table 1. There were no statistically significant difference in the age, gender, comorbidities, duration of CPB, and aortic clamping between groups (Table 1).

The characteristics of hemodynamic and tissue oxygenation parameters during surgery of groups were shown in Table 2. The glucose values were significantly different between groups. There was a statistically significant effect of DM on blood glucose values $(\mathrm{p}<.001)$ as expected. NIDDM patients had 1.67 times higher blood glucose values than those with NoDM, $(\mathrm{p}<0.05)$ [95\% CI: 1.47, 1.91]. In general, time has a positive and statistically significant effect on blood glucose levels $(\mathrm{p}<.001)$. As time progresses, blood sugar increases 1.18 times $(\mathrm{p}<0.05)$ [95\% CI: 1.17, 1.20]. When the change in the blood glucose values of the patients in the NIDDM and NoDM groups is examined, the blood glucose levels of the patients with NIDDM increase 0.879 times as time progresses, while the patients with NoDM increase $1 / 0.879=1.14$ times as time progresses (Figure 1). Hypoglycemic attack was not observed in any patient.

The $\mathrm{O}_{2} \mathrm{ER}$ values were significantly different between groups when repeated measurements were analyzed together with GEE method $(\mathrm{p}=0.004)$ (Figure 2). There is a statistically significant difference between the groups at the $4^{\text {th }}$ time point $(\mathrm{p}=0.022)$. Patients in the NIDDM group had higher $\mathrm{O}_{2} \mathrm{ER}$ values than patients in the NoDM group at time points 1, 2, and 4. NIDDM patients had 1.22 times higher $\mathrm{O}_{2}$ ER values than those with NoDM, and this result was statistically significant [95\% CI: 1.06-1.40]. There was no statistically significant effect of time on $\mathrm{O}_{2} \mathrm{ER}$ values $(\mathrm{p}=0.746)$.

There was no statistically significant effect of blood glucose values on $\mathrm{O}_{2} \mathrm{ER}(\mathrm{p}=0.549)$, and also no statistically significant effect of $\mathrm{O}_{2} \mathrm{ER}$ values on blood glucose was found $(\mathrm{p}=0.578)$.

There was no statistically difference at lactate level, $\mathrm{DO}_{2}, \mathrm{VO}_{2}, \mathrm{SVR}, \mathrm{ScvO}_{2}, \mathrm{Hb}, \mathrm{MAP}$, HR, temperature, and urine output values between groups. 
Intraoperative inotropic medications, blood product transfusion rates, postoperative complications, and mortality data were not statistically different as shown in Table 3.

\section{Discussion}

This study hypothesized that stress hyperglycemia associates with tissue perfusion. This stress response may cause reduced tissue perfusion parameters and may differ in non-diabetic patients and in patients with noninsulin-dependent diabetes mellitus undergoing cardiac surgery. The stress-induced hyperglycemic response during cardiac surgery was more severe in noDM patients than in patients with NIDDM (1.14 \& 0.879). When focusing on the $\mathrm{O}_{2}$ ER parameter in terms of tissue oxygenation, NIDDM patients had 1.22 times higher and significant $\mathrm{O}_{2}$ ER values than NoDM patients. However, blood glucose values and $\mathrm{O}_{2}$ ER parameters had no effect on each other, and/or no correlation was found between them.

Hyperglycemia is common in cardiac surgery and seen as high as $60-80 \%$ of patients. ${ }^{8,14}$ Hyperglycemia occurs as a result of decreased insulin production caused by pancreatic $\beta$ cell insufficiency, or insulin resistance. In the absence of autoimmune diabetes, transient disturbances in pancreatic cell secretion during CPB were found to be associated with hypothermia. ${ }^{15}$ However, the causes of insulin resistance are the secretion of catecholamines and cortisone against effects such as systemic inflammatory response syndrome, hemodilution, systemic heparinization together with CPB (surgical stress). ${ }^{5}$ The severity of the hyperglycemic response increases with the intensity of the stress, so in cardiac surgery, inflammation initially caused by anesthesia and surgery peaks together with CPB and hypothermia. ${ }^{16}$ In our study, blood glucose in the NoDM group which stress hyperglycemia ratio was found $78 \%$ reached its highest values at T2 and T3 periods, that is, when the effects of CPB and hypothermia effects were strongest. In the NIDDM group, blood glucose levels were above $140 \mathrm{mg} / \mathrm{dl}$ from the beginning, and also peaked during T2 and T3 periods, similar to the NoDM group. In accordance with our clinical protocol, if blood glucose rises above $180 \mathrm{mg} / \mathrm{dl}$ in the intraoperative period, continuous insulin infusion is started. A randomized controlled study of 400 diabetic and non-diabetic surgical patients comparing the two groups who received a continuous infusion of insulin to keep the intraoperative glucose level between $80-100 \mathrm{mg} / \mathrm{dL}$ and the glucose target kept below $200 \mathrm{mg} / \mathrm{dL}$ did not report any improvement in clinical outcome or complications. ${ }^{17}$ In a meta-analysis including the results of 706 cardiac surgery patients, it was reported that strict intraoperative glycemic control decreased infection rate but not mortality compared to conventional therapy. ${ }^{18} \mathrm{In}$ another coronary surgery patient group, when a blood glucose target of 90-120 mg / dL and 121-180 mg/dL was achieved, no difference was observed in deep sternum wound infection, pneumonia, perioperative renal failure, or mortality. ${ }^{19}$ Similarly, other studies targeting the same glucose values did not report any difference between the groups in terms of perioperative complications, length of stay in hospital, and mortality. ${ }^{20,21}$ Although our study population is smaller compared to these studies, we would like to state that in our results, no difference was observed between non-diabetic and NIDDM cardiac surgery patients in terms of postoperative complications and mortality. As the surgery progressed, the rate of increase in blood glucose observed in the NoDM group was higher than in the NIDDM group. Although the mechanism is not fully known, all these studies show that NIDDM provides a tolerance to stress-induced hyperglycemia, and an approach that does not require tighter control can be preferred for glycemic control with NIDDM. ${ }^{22}$

In general, global body oxygen delivery in anesthesia practice is mathematically formulated by $\mathrm{DO}_{2}$, that is the product of cardiac output and arterial oxygen content. Although medical physiological facts often do not agree with this simple mathematical calculation, interpretation can be made about tissue oxygenation by evaluating many other parameters such as $\mathrm{O}_{2} \mathrm{ER}, \mathrm{ScvO}_{2}$, lactate, systemic vascular resistance (SVR) and hemoglobin. It has been stated that global tissue hypoperfusion detected with $\mathrm{SvO}_{2}$ and lactate is common in non-diabetic coronary artery surgery patients, in addition high blood glucose level is not suitable for use as a perioperative marker for global tissue hypoperfusion. ${ }^{23}$ On the other hand, in another study, it was suggested that patients with diabetes mellitus who underwent cardiac surgery had impairments in cerebral oxygen saturation, possibly due to microcirculatory disorders, and $\mathrm{SvO}_{2}$ measurement did not reflect this deficiency. ${ }^{24}$ It is known that hyperlactatemia seen in cardiac surgery does not always indicate an anaerobic condition and/or a lack of tissue oxygen delivery, a condition called type B hyperlactatemia. ${ }^{25,26}$ Conversely, 
it has been suggested that reduced increase in lactate levels in the presence of hyperglycemia may be a result of decreased activation of the glycolytic pathway in patients with diabetes mellitus compared to patients with NoDM. ${ }^{27}$ In our study, the lactate values were around $2-3 \mathrm{mmol} / \mathrm{L}$ in both groups, which was quite acceptable during cardiac surgery and the $\mathrm{ScvO}_{2}$ value was around $70 \%$ and there was no clinical significance between the groups. No difference was found between non-diabetic and NIDDM patients in terms of other parameters such as hemoglobin, MAP, SVR and blood product transfusion, but a significant difference emerged when the $\mathrm{O}_{2}$ ER parameter was examined. Accordingly, $\mathrm{O}_{2} \mathrm{ER}$ values in both groups were above the normal value of $25 \%$, and in addition, NIDDM patients had significantly higher $\mathrm{O}_{2}$ ER values. The situations encountered with high $\mathrm{O}_{2} \mathrm{ER}$ are as follows: inadequate oxygen delivery such as hypoxia, anemia, circulatory failure; increased oxygen consumption such as increased muscle activity, exercise, shivering, seizures, and inflammation; increased metabolic rate such as hyperthermia, hyperthyroidism, catecholamine excess and massive injury; abnormal circulation, such as cyanotic shunt, arterio-venous malformation. In our study, the reason for the relatively high $\mathrm{O}_{2} \mathrm{ER}$ from the beginning of the operation in anesthetized patients may be because of inflammation, and/or increased catecholamine due to the fear of surgery, as the surgery progresses, many other factors such as hemoglobin decrease due to hemodilution, hypothermia, nonpulsatile flow come into play and the severity of inflammation increases. The critical $\mathrm{DO}_{2}$ in humans is the maximum $\mathrm{O}_{2}$ ER $\left(\mathrm{O}_{2} \mathrm{ER} 0.6-0.8\right)$ at $4 \mathrm{ml} \mathrm{kg}^{-1} \mathrm{~min}^{-1}$, and at this stage $\mathrm{VO}_{2}$ is said to be supply dependent. If $\mathrm{DO}_{2}$ continues to fall further below its critical value, anaerobic metabolism and type A hyperlactataemia occur due to the imbalance between ATP supply and demand. Although lactate values were slightly higher and $\mathrm{ScvO}_{2}$ values were slightly lower in the NIDDM group in our study, considering the fact that $\mathrm{O}_{2} \mathrm{ER}$ reflects the total outcome of small changes in all these parameters, we can emphasize the conclusion that NIDDM patients undergoing cardiac surgery have greater tissue oxygen demand/supply imbalance compared to NoDM patients. In our study, this tissue oxygenation defect in NIDDM patients was not found to be directly correlated with blood glucose levels. Perhaps, even if the disease is under control, the negative effects of diabetes on all systems have accumulated and led to such a result. Studies with more patients will shed light on the subject.

Limitations of this study; while this theoretical understanding underpins the physiology of oxygen in the critically ill patient, empirical evidence to support them is limited and the concepts remain controversial. Even if global oxygen supply and consumption appears to be normal, it does not exclude the presence of pathological oxygen supply/demand at the regional or local level. The small number of our patients is another limitation as noted earlier. And it would be more valuable if we had chance to measure cortisol levels to determine catabolic stress.

This research did not receive any specific grants from funding agencies in the public, commercial, or not-forprofit sectors.

\section{Declaration of conflicting interests}

The authors declare that there is no conlict of interest.

\section{References}

1. Estrada CA, Young JA, Nifong LW, Chitwood WR Jr. Outcomes and perioperative hyperglycemia in patients with or without diabetes mellitus undergoing coronary artery bypass grafting. Ann Thorac Surg. 2003;75(5):1392-99.

2. Anderson RE, Brismar K, Barr G, Ivert T. Effects of cardiopulmonary bypass on glucose homeostasis after coronary artery bypass surgery. Eur J Cardiothorac Surg. 2005;28(3):425-30.

3. Velissaris T, Tang AT, Murray M, Mehta RL, Wood PJ, Hett DA, Ohri SK. A prospective randomized study to evaluate stress response during beating-heart and conventional coronary revascularization. Ann Thorac Surg. 2004;78(2):506-12.

4. Ouattara A, Lecomte P, Le Manach Y, Landi M, Jacqueminet S, Platonov I, et al. Poor intraoperative blood glucose control is associated with a worsened hospital outcome after cardiac surgery in diabetic 
patients. Anesthesiology. 2005;103(4):687-94.

5. Doenst T, Wijeysundera D, Karkouti K, Zechner C, Maganti M, Rao V, Borger MA. Hyperglycemia during cardiopulmonary bypass is an independent risk factor for mortality in patients undergoing cardiac surgery. J Thorac Cardiovasc Surg. 2005;130(4):1144.

6. Szabó Z, Håkanson E, Svedjeholm R. Early postoperative outcome and medium-term survival in 540 diabetic and 2239 nondiabetic patients undergoing coronary artery bypass grafting. Ann Thorac Surg. 2002;74(3):712-9.

7. McAlister FA, Man J, Bistritz L, Amad H, Tandon P. Diabetes and coronary artery bypass surgery: an examination of perioperative glycemic control and outcomes. Diabetes Care. 2003;26(5):1518-24.

8. Carvalho G, Moore A, Qizilbash B, Lachapelle K, Schricker T. Maintenance of normoglycemia during cardiac surgery. Anesth Analg. 2004;99(2):319-24.

9. Subramaniam K, Sciortino C, Ruppert K, Monroe A, Esper S, Boisen M, et al. Remifentanil and perioperative glycaemic response in cardiac surgery: an open-label randomised trial. Br J Anaesth. 2020;124(6):684-92.

10. Lighthall GK, Singh S. Perioperative Maintenance of Tissue Perfusion and Cardiac Output in Cardiac Surgery Patients. Semin Cardiothorac Vasc Anesth. 2014;18(2):117-36.

11. J-OC Dunn, MG Mythen, MP Grocott. Physiology of oxygen transport, BJA Education, 16(10): 341-348, 2016.

12. Duggan EW, Carlson K, Umpierrez GE. Perioperative Hyperglycemia Management: An Update. Anesthesiology. 2017;126(3):547-560. Erratum in: Anesthesiology. 2018 Nov;129(5):1053.

13. Huber W, Zanner R, Schneider G, Schmid R, Lahmer T. Assessment of Regional Perfusion and Organ Function: Less and Non-invasive Techniques. Front Med (Lausanne). 2019;6:50.

14. Schmeltz LR, DeSantis AJ, Thiyagarajan V, Schmidt K, O'Shea-Mahler E, Johnson D, et al. Reduction of surgical mortality and morbidity in diabetic patients undergoing cardiac surgery with a combined intravenous and subcutaneous insulin glucose management strategy. Diabetes Care. 2007;30(4):823-8.

15. Mills NL, Beaudet RL, Isom OW, Spencer FC. Hyperglycemia during cardiopulmonary bypass. Ann Surg. 1973;177(2):203-205.

16. Shen C, Gu T, Gu L, Xiu Z, Zhang Z, Shi E, et al. Change in the perioperative blood glucose and blood lactate levels of non-diabetic patients undergoing coronary bypass surgery. Exp Ther Med. 2013;6(5):1220-4.

17. Gandhi GY, Nuttall GA, Abel MD, Mullany CJ, Schaff HV, O'Brien PC, et al. Intensive intraoperative insulin therapy versus conventional glucose management during cardiac surgery: a randomized trial. Ann Intern Med. 2007;146(4):233-43.

18. Hua J, Chen G, Li H, Hunt SL, Martin CT, Hebsur S, Ad N. Intensive intraoperative insulin therapy versus conventional insulin therapy during cardiac surgery: a meta-analysis. J Cardiothorac Vasc Anesth. 2012;26(5):829-34.

19. Desai SP, Henry LL, Holmes SD, et al. Strict versus liberal target range for perioperative glucose in patients undergoing coronary artery bypass grafting: a prospective randomized controlled trial. J Thorac Cardiovasc Surg. 2012 Feb;143(2):318-325. doi: 10.1016/j.jtcvs.2011.10.070.

20. Lazar HL, McDonnell MM, Chipkin S, Fitzgerald C, Bliss C, Cabral H. Effects of aggressive versus moderate glycemic control on clinical outcomes in diabetic coronary artery bypass graft patients. Ann Surg. 2011;254(3):458-63.

21. Pezzella AT, Holmes SD, Pritchard G, Speir AM, Ad N. Impact of perioperative glycemic control strategy on patient survival after coronary bypass surgery. Ann Thorac Surg. 2014 Oct;98(4):1281-1285. doi: 10.1016/j.athoracsur.2014.05.067. 
22. Preiser JC, Chase JG, Hovorka R, Joseph JI, Krinsley JS, De Block C, et al. Glucose Control in the ICU: A Continuing Story. J Diabetes Sci Technol. 2016;10(6):1372-81.

23. Das S, Ghosh K, Hazra A, Sen C, Goswami A. Is elevated blood glucose a marker of occult tissue hypoperfusion in off-pump coronary artery bypass grafting? Ann Card Anaesth. 2018;21(4):393-401.

24. Sudy R, Petak F, Schranc A, Agocs S, Blaskovics I, Lengyel C, Babik B. Differences Between Central Venous and Cerebral Tissue Oxygen Saturation in Anaesthetised Patients With Diabetes Mellitus. Sci Rep. 2019; 24;9(1):19740.

25. Stephens EH, Epting CL, Backer CL, Wald EL. Hyperlactatemia: An Update on Postoperative Lactate. World J Pediatr Congenit Heart Surg. 2020;11(3):316-24.

26. Maillet JM, Le Besnerais P, Cantoni M, Nataf P, Ruffenach A, Lessana A, Brodaty D. Frequency, risk factors, and outcome of hyperlactatemia after cardiac surgery. Chest. 2003;123(5):1361-6.

27. Greco G, Kirkwood KA, Gelijns AC, Moskowitz AJ, Lam DW. Diabetes Is Associated With Reduced Stress Hyperlactatemia in Cardiac Surgery. Diabetes Care. 2018;41(3):469-477.

Table 1: Demographic and clinical characteristics of the study population

\begin{tabular}{|c|c|c|c|}
\hline Variables & Group NoDM $(\mathrm{n}=64)$ & Group NIDDM $(\mathrm{n}=19)$ & p-value \\
\hline $\begin{array}{l}\text { Age (years) (Median } \\
\text { (Range)) }\end{array}$ & $58(60)$ & $62(30)$ & $0.244^{¥}$ \\
\hline Male Gender (n/\%) & $47(73.4)$ & $15(78.9)$ & 0.769 \\
\hline $\begin{array}{l}\text { Weight }(\mathrm{kg}) \text { (Median } \\
\text { (Range)) }\end{array}$ & $78(49)$ & $74(50)$ & $0.218^{¥}$ \\
\hline $\begin{array}{l}\text { Height (cm) (Median } \\
\text { (Range)) }\end{array}$ & $170(45)$ & $165(28)$ & $0.213^{¥}$ \\
\hline $\begin{array}{l}\text { Body Mass Index } \\
\text { (Median (Range)) }\end{array}$ & $0.28(0.15)$ & $0.26(0.14)$ & $0.481^{¥}$ \\
\hline Hypertension (n/\%) & $23(35.9)$ & $12(63.2)$ & 0.065 \\
\hline $\begin{array}{l}\text { Chronic obstructive } \\
\text { pulmonary disease } \\
\text { (n/\%) }\end{array}$ & $5(7.8)$ & $1(5.3)$ & 1.000 \\
\hline $\begin{array}{l}\text { Cerebrovascular } \\
\text { accident }(\mathrm{n} / \%)\end{array}$ & $2(3.1)$ & $1(5.3)$ & 0.547 \\
\hline $\begin{array}{l}\text { Operation duration } \\
\text { (hours) (Median } \\
\text { (Range)) }\end{array}$ & $5.0(5.5)$ & $5.0(5.0)$ & $0.161^{¥}$ \\
\hline $\begin{array}{l}\text { CPB duration (min) } \\
\text { (Median (Range)) }\end{array}$ & $107(202)$ & $96(209)$ & $0.209^{¥}$ \\
\hline $\begin{array}{l}\text { Cross clamping } \\
\text { duration (min) } \\
\text { (Median (Range)) }\end{array}$ & $69.5(165)$ & $57(164)$ & $0.257^{¥}$ \\
\hline
\end{tabular}

: Chi-square test

${ }^{¥}$ : Mann-Whitney-U test

CPB: Cardiopulmonary bypass

Table 2: Intraoperative datas during time points 


\begin{tabular}{|c|c|c|c|c|}
\hline Variables & $\begin{array}{l}\text { Group NoDM } \\
(\mathrm{n}=64)\end{array}$ & $\begin{array}{l}\text { Group NIDDM } \\
(\mathrm{n}=19)\end{array}$ & p-value & p-value \\
\hline Glucose T1 & 101.5 & $153(167)$ & $<.001^{* ¥}$ & $<.001^{*}$ \\
\hline $\mathrm{T} 2$ & $127.5(127)$ & $170(159)$ & $<.001^{* ¥}$ & \\
\hline $\mathrm{T} 3$ & $165(182)$ & $193(115)$ & $0.015^{* ¥}$ & \\
\hline $\mathrm{T} 4$ & $171(186)$ & $182(104)$ & $0.599^{¥}$ & \\
\hline Lactate $\mathrm{T} 1$ & $0.90(2.3)$ & $0.90(1.5)$ & $0.568^{¥}$ & 0.426 \\
\hline $\mathrm{T} 2$ & $2.30(4.7)$ & $3.10(6.4)$ & $0.271^{¥}$ & \\
\hline $\mathrm{T} 3$ & $2.40(6.3)$ & $2.70(7.1)$ & $0.660^{¥}$ & \\
\hline $\mathrm{T} 4$ & $2.75(6.8)$ & $2.70(7.2)$ & $0.425^{¥}$ & \\
\hline $\mathrm{DO}_{2} \mathrm{~T} 1$ & $915.19(1954.69)$ & $798.15(1562.92)$ & $0.229^{¥}$ & 0.609 \\
\hline $\mathrm{T} 2$ & $525.26(388.80)$ & $473.34(266.80)$ & $0.095^{¥}$ & \\
\hline T3 & $497.00(492.10)$ & $450.00(303.53)$ & $0.237^{¥}$ & \\
\hline $\mathrm{T} 4$ & $729.5(1315.14)$ & $647.28(718.03)$ & $0.186^{¥}$ & \\
\hline $\mathrm{VO}_{2} \mathrm{~T} 1$ & $256.72(537.03)$ & $243.92(444.26)$ & $0.803^{¥}$ & 0.575 \\
\hline $\mathrm{T} 2$ & $166.13(206.28)$ & $179.22(179.11)$ & $0.862^{¥}$ & \\
\hline T3 & $136.27(204.55)$ & $118.21(219.17)$ & $0.061^{¥}$ & \\
\hline $\mathrm{T} 4$ & $204.40(455.19)$ & $211.88(599.82)$ & $0.786^{¥}$ & \\
\hline $\mathrm{O}_{2} \mathrm{ER} \mathrm{T} 1$ & $0.28(0.32)$ & $0.31(0.27)$ & $0.201^{¥}$ & $0.004^{*}$ \\
\hline $\mathrm{T} 2$ & $0.31(0.49)$ & $0.33(0.26)$ & $0.091^{¥}$ & \\
\hline T3 & $0.29(0.53)$ & $0.28(0.28)$ & $0.343^{¥}$ & \\
\hline $\mathrm{T} 4$ & $0.28(0.42)$ & $0.32(0.41)$ & $0.022^{* ¥}$ & \\
\hline SVR T1 & $1295(2430)$ & $1270(1280)$ & $0.978^{¥}$ & 0.378 \\
\hline $\mathrm{T} 4$ & $820(1460)$ & $940(1090)$ & $0.165^{¥}$ & \\
\hline $\mathrm{ScvO}_{2} \mathrm{~T} 1$ & $0.73(0.36)$ & $0.71(0.29)$ & $0.198^{¥}$ & 0.080 \\
\hline $\mathrm{T} 2$ & $0.76(0.53)$ & $0.74(0.30)$ & $0.266^{¥}$ & \\
\hline $\mathrm{T} 3$ & $0.73(0.61)$ & $0.76(0.47)$ & $0.305^{¥}$ & \\
\hline $\mathrm{T} 4$ & $0.71(0.37)$ & $0.69(0.40)$ & $0.037^{* ¥}$ & \\
\hline Hemoglobin T1 & $13.70(8.5)$ & $13(4.6)$ & $0.132^{¥}$ & 0.063 \\
\hline $\mathrm{T} 2$ & $8.55(5.9)$ & $7.5(5.1)$ & $0.059^{¥}$ & \\
\hline $\mathrm{T} 3$ & $8.45(6.1)$ & $8.1(3.7)$ & $0.248^{¥}$ & \\
\hline $\mathrm{T} 4$ & $8.75(5.9)$ & $8.2(3.5)$ & $0.235^{¥}$ & \\
\hline MAP T1 & $76.33(53.0)$ & $81(44)$ & $0.380^{¥}$ & 0.606 \\
\hline $\mathrm{T} 2$ & $62(50)$ & $63(40)$ & $0.438^{¥}$ & \\
\hline T3 & $70(40)$ & $76(33)$ & $0.368^{¥}$ & \\
\hline $\mathrm{T} 4$ & $68.67(42)$ & $73(33)$ & $0.213^{¥}$ & \\
\hline Heart rate $\mathrm{T} 1$ & $68.33 \pm 14.07$ & $69.68 \pm 9.76$ & $0.696^{\mathrm{v}}$ & 0.624 \\
\hline $\mathrm{T} 4$ & $85.84 \pm 13.88$ & $86.11 \pm 14.86$ & $0.944^{\mathrm{v}}$ & \\
\hline Temperature T1 & $36.5(2.1)$ & $36.4(1.8)$ & $0.069^{* ¥}$ & 0.720 \\
\hline $\mathrm{T} 2$ & $32.0(6.7)$ & $32.0(4.0)$ & $0.982^{¥}$ & \\
\hline $\mathrm{T} 3$ & $30.0(5.0)$ & $31.0(3.0)$ & $0.152^{¥}$ & \\
\hline $\mathrm{T} 4$ & $37.0(4.7)$ & $36.8(2.8)$ & $0.713^{¥}$ & \\
\hline $\begin{array}{l}\text { Urine output } \\
\text { (cumulative) } \mathrm{T} 1\end{array}$ & $50(350)$ & $20(500)$ & $0.660^{¥}$ & 0.753 \\
\hline $\mathrm{T} 2$ & $200(880)$ & $150(970)$ & $0.836^{¥}$ & \\
\hline $\mathrm{T} 3$ & $500(1800)$ & $400(1050)$ & $0.295^{¥}$ & \\
\hline $\mathrm{T} 4$ & $1050(2750)$ & $700(1850)$ & $0.109^{¥}$ & \\
\hline
\end{tabular}

Values are presented as median (range) or mean \pm standard deviation

$\mathrm{DO}_{2}$ : Oxygen delivery, $\mathrm{VO}_{2}$ : Oxygen consumption, $\mathrm{O}_{2} \mathrm{ER}$ : Oxygen extraction rate, SVR: Systemic vascular 
rezistance, $\mathrm{ScvO}_{2}$ : Central venous oxygen saturation, MAP: Mean arterial pressure

$¥$ : Mann-Whitney-U test

: GEE method

v: Independent two-sample test

$*: p<0.05$

Table 3: Intraoperative and postoperative variables of the study population

\begin{tabular}{llll}
\hline Variables & Grup NoDM $(\mathrm{n}=64)$ & Grup NIDDM $(\mathrm{n}=19)$ & $\mathrm{p}$-value \\
\hline $\begin{array}{l}\text { Intraoperative } \\
\text { transfusion n(\%) }\end{array}$ & $9(14.1)$ & $3(15.8)$ & 1.000 \\
$\begin{array}{l}\text { Intraoperative } \\
\text { inotropic infusions }\end{array}$ & & - \\
$\mathrm{n}(\%)$ & & \\
Dopamine & $4(6.3)$ & $3(15.8)$ & \\
Dobutamine & $4(6.3)$ & $0(0.0)$ & \\
Noradrenaline & $2(3.1)$ & $0(0.0)$ & 1.000 \\
Major adverse cardiac & $6(9.4)$ & $2(10.5)$ & 1.000 \\
events n(\%) & $1(1.6)$ & $1(5.3)$ & 0.408 \\
Cerebrovascular & $1(1.6)$ & $1(5.3)$ & - \\
accident n(\%) & $0(0.0)$ & $0(0.0)$ & - \\
Tamponade $\mathrm{n}(\%)$ & $0(0.0)$ & $0(0.0)$ & - \\
Respiratory & $0(0.0)$ & $0(0.0)$ & - \\
complications $\mathrm{n}(\%)$ & $0(0.0)$ & & \\
Renal complications & & & \\
Sternal wound infection & $0(0.0)$ & \\
Mortality & & & \\
\hline
\end{tabular}

-: Chi-square assumptions are not met.

\section{Figure Legends}

Figure 1: Blood glucose levels during four intraoperative time points.

Figure 2: The $\mathrm{O}_{2}$ ERs during four intraoperative time points

\section{Hosted file}

Figure 1.docx available at https://authorea.com/users/345571/articles/542011-intraoperativehyperglycemic-stress-response-and-tissue-perfusion-in-cardiac-surgery

\section{Hosted file}

Figure 2.docx available at https://authorea.com/users/345571/articles/542011-intraoperativehyperglycemic-stress-response-and-tissue-perfusion-in-cardiac-surgery 